\title{
Goat Milk Yoghurt by Using Lacto-B Culture Modulates the Production of Tumor Necrosis Factor-Alpha and Interleukin-10 in Malnourished Rats
}

\author{
Nurliyani*, BJ. Istiti Kandarina1, Sari Kusuma², and Yunita Dewi Trisnasari² \\ Department of Animal Product Technology, Faculty of Animal Science, Universitas Gadjah Mada, Yogyakarta, Indonesia \\ ${ }^{1}$ Department of Public Health, Faculty of Medicine, Universitas Gadjah Mada, Yogyakarta, Indonesia \\ ${ }^{2}$ Department of Nutrition and Health, Faculty of Medicine, Universitas Gadjah Mada, Yogyakarta, Indonesia
}

\begin{abstract}
Total spleen lymphocytes, lymphocyte proliferation, tumor necrosis factor- $\alpha$ (TNF- $\alpha$ ), and interleukin-10 (IL-10) in spleen lymphocyte culture were studied in malnourished Wistar rats fed with goat milk yoghurt. Malnourished rats were created by using standard feed restriction as much as $50 \%$ of normal rats for $21 \mathrm{~d}$. Goat milk yoghurt containing three types of microorganism e.g., Lactobacillus acidophilus, Sterptococcus thermophilus and Bifidobacterium longum derived from Lacto-B culture in powder form. After $21 \mathrm{~d}$, the rats continued to receive restricted feeding and supplemented with goat milk yoghurt for $7 \mathrm{~d}$. Total splenocytes were counted by hemocytometer. Splenocytes proliferation was expressed as stimulation index, whereas the TNF- $\alpha$ and IL-10 of spleen lymphocyte culture were measured by ELISA technique. The total number of splenocytes and stimulation index of splenocytes in moderate malnourished and normal rats supplemented with goat milk yoghurt was not significantly different. The level of TNF- $\alpha$ in the rat supplemented with goat milk yoghurt was lower $(p<0.05)$ than the control group, whereas the level of IL-10 in the rat supplemented with goat milk yoghurt was higher $(p<0.05)$ than the control group. In conclusion, goat milk yoghurt supplementation in malnourished rats could decrease TNF- $\alpha$ as a representation of the pro-inflammatory cytokine, while it increases IL-10 as a representation of the anti-inflammatory cytokine.
\end{abstract}

Key words: goat milk yoghurt, IL-10, lymphocyte proliferation, malnutrition, TNF- $\alpha$

\section{Introduction}

Goat milk has many advantages in terms of percentage of an over-sized fat droplets smaller than cow's milk (Silanikove et al., 2010). Because the goat milk fat globule has a greater surface area, and lipases in the gut are supposedly able to attack the lipids more rapidly. Almost $20 \%$ of the fatty acids of goat milk fall into the shortchain fatty acids category ( $\mathrm{C} 4: \mathrm{O}$ to $\mathrm{C} 12: \mathrm{O})$ compared with $10-20 \%$ for cow milk. Lipases attack the ester linkages of the shorter-chain fatty acids more readily, so these differences may contribute to more rapid digestion and absorption of goat milk fat (Arora et al., 2013). Some physicochemical properties of goat milk such as smaller fat globules, higher percentage of short and medium chain fatty acids, and softer curd formation of its proteins

\footnotetext{
*Corresponding author: Nurliyani, Department of Animal Product Technology. Faculty of Animal Science, Universitas Gadjah Mada, Jl. Fauna 3 Kampus UGM, Bulaksumur, Yogyakarta 55281, Indonesia. Tel: 62274-513363. Fax: 62274-521578, Email: nurliyani@yahoo.com
}

are advantageous for higher digestibility and healthier lipid metabolism relative to cow milk (Park, 1994). Thus goat milk has been recommended for either infants, old, convalescent people (Kompan and Komprej, 2012), and goat milk-based diet (animal fat) has a benefecial effect and thus its consumption may be recommended especially in cases of malabsorption syndromes (Alferez et al., 2001). Goat milk has a nutritional value similar to that of cow milk and could be used as an alternative to cow milk for rehabilitating undernourished children (Razafindrakoto et al., 1993).

The prevalence of malnutrition in Indonesia is still relatively high despite a declining trend from 2007 to 2010 . The proportion of malnourished children under five in Indonesia decreased from $18.4 \%$ in 2007 to $17.9 \%$ in 2010 (Riskesdas, 2010). Protein malnutrition disrupts the normal ecology of the microflora affecting strictly anaerobes, impairs host immune response and antibacterial defenses, enhances the susceptibility to infection, and leads to mucosal atrophy (Dock et al., 2004). The direct relationship between malnutrition and death is mainly due to the immunodeficiency status and consequently, greater 
susceptibility to infectious agents (Franca et al., 2009). The severity of the malnutrition depends on the degree of nutrient imbalance and the interaction between nutrients and the age of the host (Nunez et al., 2013). Severe protein malnutrition, mainly in newborns and small children, also provokes thymus atrophy that, in turn, reduces thymus cell number and also severely affects the development of peripheral lymphoid organs. The immediate consequence of this atrophy is leucopenia, decreased CD4/ CD8 ratio and increased number of immature $\mathrm{T}$ cells in the periphery (Savino, 2002).

The spleen has a very high blood flow, that it filters off cell-free fluid from the blood into the lymphatic system and that the rate of filtration is modulated by neuronal and humoral factors (Semaeva et al., 2010). The spleen was chosen as a representative of systemic lymphoid organ to evaluate the systemic immune system status (Ramiro-Puig et al., 2007).

The induction of proinflammatory and anti-inflammatory cytokines is important in determining whether the immune system is successful in providing protection against specific pathogenic organisms (Al-Bana et al., 2008). Production TNF- $\alpha$ by bone marrow cells is also significantly lower in malnourished animals (França et al., 2009).

Probiotic yoghurt intake was associated with significant anti-inflammatory effects that paralleled the expansion of peripheral pool of putative $T$ regulatory (Treg) cells in inflammatory bowel disease (IBD) patients (Baroja et al., 2007). The concept that probiotics act via the induction of regulatory cells is inherently attractive, because it seems unlikely that they could act by adequately replacing all bacteria in the intestinal microflora that are capable of causing inflammation in experimental mice/individuals susceptible to IBD-like inflammation or IBD (Giacinto et al., 2005). Several different mechanism of probiotics are: 1) involves altering the composition of the intestinal microbiota by producing bacteriocins, which are products that eliminate certain bacteria, or by altering $\mathrm{pH}$, which will alter the growth characteristics of certain bacteria, 2) involves altering the epithelial barrier function of the intestine, and 3) have important immunoregulatory activity, so certain probiotics and their products can activate regulatory $\mathrm{T}$ cells and regulatory pathways, leading to downregulation of inflammation (Sartor, 2011). The previous study by Giacinto et al. (2005) showed that probiotic administration was associated with an early increase in the production of IL-10 and an increased number of regulatory $\mathrm{CD}^{+} \mathrm{T}$ cells. The increase in $\mathrm{CD} 4^{+} \mathrm{CD} 25^{\text {high }}$ $\mathrm{T}$ cells correlated with the decrease in the percentage of
TNF- $\alpha$ - or IL-12-producing monocytes and dendritic cell (DC) (Baroja et al., 2007).

Recently, yoghurt are often added by probiotics to improve health effects, and originally yoghurt is made using a starter Lactobacillus bulgaricus and Streptococcus thermophilus cultures that can be derived from the powder or liquid culture. Probiotic such as Bifidobacterium longum reported by the previous study (Pavlovic et al., 2006) grew better in goat milk than in cow milk. According to Dock et al. (2004), S. thermophilus and L. helveticus enhance the recovery of gut atrophy induced by malnutrition.

In this study, yoghurt was made directly using Lacto-B powder which inoculated into the milk. Lacto-B is a non dairy powder-containing probiotic consists of $B$. longum, $L$. acidophilus, and $S$. thermophilus known as treatment for diarrhea. Probiotic strains such as Lactobacillus species, Bifidobacterium species and Streptococcus species have long history of safe use and are Generally Recognized As Safe (GRAS). Multi-strain and multi-species probiotics have improved functionality as compared to single strain (Dash, 2009). This study aimed to determine the effect of goat milk yoghurt which is made with culture from Lacto-B powder on total of rat splenocytes, splenocyte proliferation, levels of TNF- $\alpha$ and IL-10 in splenocyte culture supernatant of malnourished rats.

\section{Materials and Methods}

\section{Goat milk yoghurt preparation}

Goat milk yoghurt was prepared from goat milk of Etawah Crossedbred from Indonesia and culture of Lacto-B powder. Goat milk was pasteurized at $85^{\circ} \mathrm{C}$ for $30 \mathrm{~min}$ and cooled to $43-45^{\circ} \mathrm{C}$. After cooled, pasteurized goat milk was inoculated with 3\% Lacto-B powder (Novell Pharmaceutical Laboratories) containing $S$. thermophilus, $L$. acidophilus and B. longum and incubated at $45^{\circ} \mathrm{C}$ for $6 \mathrm{~h}$ (Dave, 1998; Sunarlim, 2009 with slight modification).

\section{Experimental animals}

Three week old male Wistar rats weighing 25.5-41.0 g, were individually caged and housed. During $7 \mathrm{~d}$ the rats fed unrestricted amounts of a standard laboratory diet AIN93G (Reeves et al., 1993) and then randomly assigned to two groups: one maintained in the same conditions (control) and another group fed $50 \%$ of the intake of the control's (restricted or malnourished) (Rosso et al., 1981) for $21 \mathrm{~d}$. Both groups were allowed to drink water ad libitum. After $21 \mathrm{~d}$, the rat were assigned to four groups: 1) Malnourished rats (MC), 2) Malnourished rats with goat milk 
yoghurt (MY), 3) Normal rats (NC), and 4) Normal rats with goat milk yoghurt (NY). MC and NC groups (control without yoghurt) were given aquadest with a volume equal to the volume of treated yoghurt. Aquadest as control or yoghurt were given orally with force feeding. The dose of goat milk yoghurt was $2 \mathrm{~mL} / 100 \mathrm{~g}$ body weight/ day, whose consumption is equivalent to the children consumption of $100 \mathrm{~mL}$ yoghurt/day (WHO, 2006). Each group of rat using 7 replications ( $\mathrm{n}=7$ rats). Rat body weight was measured every $3 \mathrm{~d}$. All of groups were treated for $7 \mathrm{~d}$, and then were killed. Lymphocytes are isolated from rat spleen for cultured. All procedures related to animal experiment were conducted following the recommendation of Medical and Health Research Ethics Committee (MHREC) Faculty of Medicine Universitas Gadjah Mada, Indonesia (KE/FK/753/EC).

\section{Lympocyte proliferation assay}

Lymphocyte proliferation was assayed according to Jain et al. (2008) with slight modifications. Spleen was removed and placed in $10 \mathrm{~mL}$ of RPMI 1640 (Sigma) media containing 10\% fetal bovine serum (FBS) (Gibco) and 2\% penicillin-streptomycin (Gibco). The spleen was washed with RPMI media. Aseptically collected spleen tissues were gently teased with sterile needles and forceps to release splenocytes into the RPMI 1640 (Sigma) media containing $10 \%$ FBS and $2 \%$ penicillin-streptomycin. Tissue suspensions were allowed to stand for $2 \mathrm{~min}$ to sediment large tissue clumps. The upper portion containing splenocytes was collected and centrifuged at $1000 \times g$ for $5 \mathrm{~min}$ at $40^{\circ} \mathrm{C}$. Suspension was incubated with erythrocyte lysis buffer $\left(0.17 \mathrm{M}\right.$ Tris $\mathrm{HCl}$ and $\left.0.16 \mathrm{M} \mathrm{NH}_{4} \mathrm{Cl}, \mathrm{pH} 7.2\right)$ for $1 \mathrm{~min}$ and washed twice by centrifuging as above with RPMI 1640 medium. Cell viability was checked by trypan blue ( $0.4 \%$ solution) and counted by haemacytometer. Viable splenocytes $\left(1.5 \times 10^{6}\right.$ cells $\left./ \mathrm{mL}\right)$ were finally cultured in heat inactivated 10\% FBS enriched RPMI 1640 medium supplemented with or without mitogen $5 \mu \mathrm{g} / \mathrm{mL}$ phytohaemagglutinine (PHA) (Murex) and incubated at $37^{\circ} \mathrm{C}$ in a humidified atmosphere of $5 \% \mathrm{CO}_{2}$ incubator for $72 \mathrm{~h}$. Then, $10 \mu \mathrm{L}$ of methylthiazoletetrazolium (MTT) $(5 \mathrm{mg} / \mathrm{mL})$ was added in each well and incubated for $4 \mathrm{~h}$ at $37^{\circ} \mathrm{C}$. Acidified isopropanol $(100 \mu \mathrm{L}$ of $0.1 \mathrm{~N} \mathrm{HCl}$ in anhydrous isopropanol) was added and mixed thoroughly to dissolve the dark blue crystals of formazan. Formazan quantification was performed using an Enzyme-linked immunosorbent assay (ELISA) plate reader with $550 \mathrm{~nm}$. The lymphocyte proliferation was expressed as stimulation index (SI) which was calculated as the corrected ab- sorbance of mitogen-stimulated cells divided by the corrected absorbance of unstimulated cells (Keller et al., 2005).

\section{Measurement of cytokine levels (TNF- $\alpha$ and IL-10)}

Splenocytes were cultured as described above, and supernatant was collected after $72 \mathrm{~h}$ to analyze cytokine levels. Rat specific ELISA kits for measurement of TNF- $\alpha$ and IL-10 (eBioscience, Bender MedSystem, Vienna, Austria) were used. Assays were performed according to instruction provided by the manufacturers. Briefly, microwell plate was washed twice with Wash Buffer. The Standard was reconstituted with $250 \mu \mathrm{L}$ aquabidest for Standard of TNF- $\alpha$, and $380 \mu \mathrm{L}$ of aquabidest for IL-10, and then prepared standard with 1:2 dilution in small tube. For TNF- $\alpha$ : $225 \mu \mathrm{L}$ of reconstituted standard TNF- $\alpha$ (concentration $=5 \mathrm{ng} / \mathrm{mL}$ ) was pipetted into S1 tube (standard 1) containing $225 \mu \mathrm{L}$ Sample Diluent (concentration $=2500$ $\mathrm{pg} / \mathrm{mL}$ ). This procedure was done for the next tubes until the concentration of the final tube (S7) was $39.1 \mathrm{pg} / \mathrm{mL}$. The procedure for analysis of IL-10 was the same as TNF$\alpha$ analysis. For IL-10: $225 \mu \mathrm{L}$ of reconstituted standard (concentration $=2000 \mathrm{pg} / \mathrm{mL}$ ) was pipetted into S1 tube (standard 1) containing $225 \mu \mathrm{L}$ Sample Diluent (concentration $=1000 \mathrm{pg} / \mathrm{mL})$. The $\mathrm{S} 1$ standard $(225 \mu \mathrm{L})$ was transferred into $\mathrm{S} 2$ standard tube (concentration $=500 \mathrm{pg} / \mathrm{mL}$ ), and continue this procedure was done for the next tubes until the concentration of the final standard (S7) was 15.6 $\mathrm{pg} / \mathrm{mL}$. Each standard $(100 \mu \mathrm{L})$ was pipetted into well for standard, and $100 \mu \mathrm{L}$ of Sample Diluent was pipetted into well for blank. Each well for sample was filled with $50 \mu \mathrm{L}$ of Sample Diluent and added $50 \mu \mathrm{L}$ sample. Biotin conjugate solution was added into microwell plate, and covered with adeshive film. The plate was incubated at room temperature $\left(18-25^{\circ} \mathrm{C}\right)$ for $2 \mathrm{~h}$. Adhesive film was removed, and washed microwell plate 4 times with $400 \mu \mathrm{L}$ Wash Buffer for each well. Streptavidin-HRP solution $(100 \mu \mathrm{L})$ was added into all well, and covered with adhesive film. The plate was incubated at room temperature for $1 \mathrm{~h}$. Micro plate was washed 4 times, whereas washing for plate in IL-10 assay as much as 3 times, and added $100 \mu \mathrm{L}$ tetramethyl-benzidine (TMB) substrate into wells. The plate was incubated at room temperature for $10 \mathrm{~min}$, and avoided from direct exposure to light. The enzyme reaction was stopped by pipetting $100 \mu \mathrm{L}$ of Stop Solution into each well. The absorbance of each microwell was read on ELISA plate reader $405 \mathrm{~nm}$. Washing for plate in IL-10 assay as much as 3 times. 


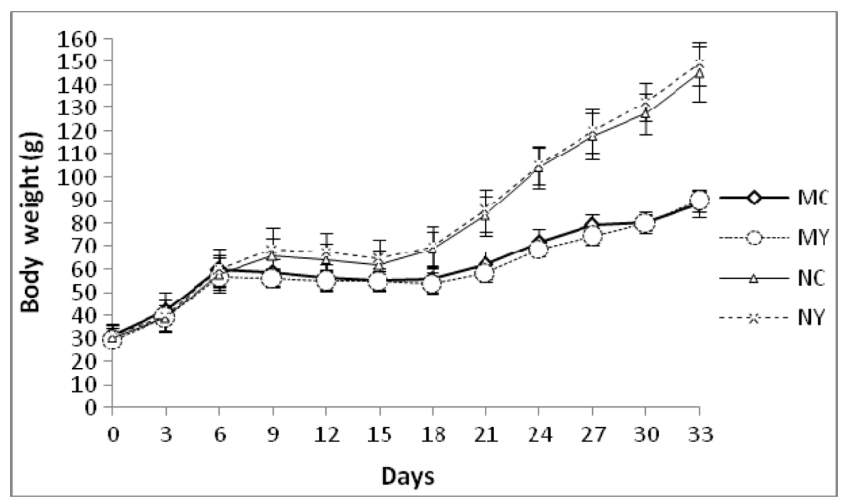

Fig. 1. Body weight (g) of malnourished and normal rats. (day 0-6: adaptation; day 6-27: restriction feeding; day 27-33: yogurt supplementation and continued restricted feeding. MC: Malnourished-control; MY: Malnourished-yoghurt; NC: Normal-control; NY: Normal-yoghurt)

\section{Statistical analysis}

The data of total splenocytes, lymphocyte proliferation, TNF- $\alpha$ and IL-10 levels of supernatant lymphocyte culture in malnourished and normal rats supplemented with goat milk yoghurt, were analyzed by ANOVA using SPSS 12.0 (2003).

\section{Results}

To study the effects of goat milk yoghurt containing $S$. thermophilus, L. acidophilus and B. longum on improvement the immunity of malnourished rats, the goat milk yoghurt has been supplemented for $7 \mathrm{~d}$ after $21 \mathrm{~d}$ received restricted feeding and continued restricted feeding together with goat milk yoghurt supplemented.

\section{Effects on body weight}

The rat body weight that received $50 \%$ restricted feeding and normal rats for $21 \mathrm{~d}$ and after supplemented with goat milk yoghurt is showed on Fig. 1.

A $50 \%$ restricted feeding resulted in moderate malnutrition, because the weight gain of malnourished rats in this study after malnutrition period for $21 \mathrm{~d}$ only $30.56 \%$ of normal rats. After restriction feeding period, the malnourished rats have lower $(p<0.05)$ body weight than the normal rats (Table 1).

Body weight of rats after $7 \mathrm{~d}$ received goat milk yoghurt and continue restricted feeding given in Table 2 .

Based on Table 1 and 2, increasing of body weight of malnourished rat supplemented with goat milk yoghurt was higher (near twice: $89.40-73.93=15.47 \mathrm{~g}$ ) than the control $(88.16-78.77=9.39 \mathrm{~g})$ rats. However, the body weight of malnourished rats significantly lower $(p<0.05)$ than the normal rats (Table 2).

\section{Effect on total splenocytes}

To study the immunity of malnourished rats, splenocytes counts were quantified. The results showed that the average of splenocytes counts of malnourished and normal rats treated with goat milk yoghurt was not significantly different with the control rats (Table 3).

\section{Effects on lympocyte proliferation}

Measurement of the proliferative response of lympho-

Table 1. Body weight (g) of rats after $21 \mathrm{~d}$ of restriction feeding and normal rats before supplemented with goat milk yoghurt

\begin{tabular}{cccc}
\hline \hline Rats & $\begin{array}{c}\text { Before supplemented } \\
\text { goat milk yoghurt }\end{array}$ & Control & Average \\
\hline Malnourished (Restricted feeding) & $73.93 \pm 3.48^{\mathrm{a}}$ & $78.77 \pm 5.03^{\mathrm{a}}$ & $76.35 \pm 4.86^{\mathrm{a}}$ \\
Normal & $119.79 \pm 9.28^{\mathrm{b}}$ & $117.61 \pm 10.15^{\mathrm{b}}$ & $118.70 \pm 9.41^{\mathrm{b}}$ \\
\hline
\end{tabular}

Superscript with the different letters indicates significantly different $(p<0.05)$.

Table 2. Body weight (g) of malnourished and normal rats treated with goat milk yoghurt

\begin{tabular}{cccc}
\hline \hline Rats & $\begin{array}{c}\text { After supplemented } \\
\text { Goat milk yoghurt }\end{array}$ & Control & Average \\
\hline Malnourished & $89.40 \pm 4.56^{\mathrm{a}}$ & $88.16 \pm 5.97^{\mathrm{a}}$ & $88.78 \pm 5.14^{\mathrm{a}}$ \\
Normal & $148.92 \pm 9.27^{\mathrm{b}}$ & $144.67 \pm 11.86^{\mathrm{b}}$ & $146.80 \pm 10.46^{\mathrm{b}}$ \\
\hline
\end{tabular}

Superscript with the different letters indicates significantly different $(p<0.05)$.

Table 3. Splenocytes count $\left(\times 10^{6}\right)$ of malnourished and normal rats treated with goat milk yoghurt

\begin{tabular}{cccc}
\hline \hline Rats & Goat milk yoghurt & Control & Average \\
\hline Malnourished & $43.00 \pm 18.04^{\mathrm{a}}$ & $32.93 \pm 11.25^{\mathrm{a}}$ & $37.96 \pm 15.36$ \\
Normal & $38.71 \pm 8.90^{\mathrm{a}}$ & $47.07 \pm 17.32^{\mathrm{a}}$ & $42.89 \pm 13.92$ \\
Average & $40.85 \pm 13.85$ & $40.00 \pm 15.83$ & $40.42 \pm 14.60$ \\
\hline
\end{tabular}

Superscript with the same letter indicates not significantly different. 


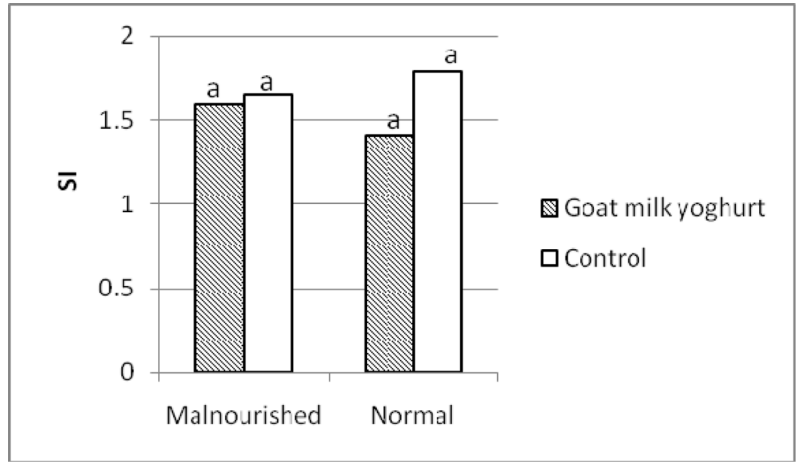

Fig. 2. Stimulation index (SI) of splenocytes of malnourished and and normal rat treated with goat milk yoghurt. (superscript with the same letter indicates not significantly different)

cytes is the most commonly used technique for evaluating cell-mediated immune response. Quantitative analysis of proliferative response involves measuring the number of cells in culture in the presence and absence of a stimulatory agent such as an antigen or a mitogen. Concanavalin A (Con A) and PHA stimulate T cells (Meydani and Ha, 2000).

Lymphocyte proliferation that was expressed as an stimulation index of lymphocytes in malnourished and normal rat was not significantly different. Furthermore, no significant changes were also observed in stimulation index of lymphocytes of rat treated with goat milk yoghurt for $7 \mathrm{~d}$ compared to the control in normal and malnourished rat (Fig. 2).

The average of lymphocyte stimulation index in the malnourished and normal rats supplemented with goat milk yoghurt was $1.62 \pm 0.68$ and $1.60 \pm 0.72$, respectively.

\section{Effect on TNF- $\alpha$ level in splenocyte culture super- natant}

Levels of TNF- $\alpha$ was significantly decreased $(p<0.05)$ in supernatant of cutured splenocytes from rat received goat milk yoghurt for $7 \mathrm{~d}$ compared to the control rat (Fig. 3 ), whereas TNF- $\alpha$ levels in malnourished and normal rat were not significantly different. The average of TNF- $\alpha$ in rats supplemented with goat milk yoghurt was $19.90 \pm 5.87$ $\mathrm{pg} / \mathrm{mL}$, whereas in the control rat was $25.01 \pm 4.08 \mathrm{pg} / \mathrm{mL}$.

\section{Effect on IL-10 level in splenocyte culture superna- tant}

Goat milk yoghurt that supplemented in malnourished and normal rats increased level of IL-10 in spleen lymphocyte culture significantly $(p<0.05)$ (Fig. 4$)$. The average of IL-10 rats supplemented with goat milk yoghurt was

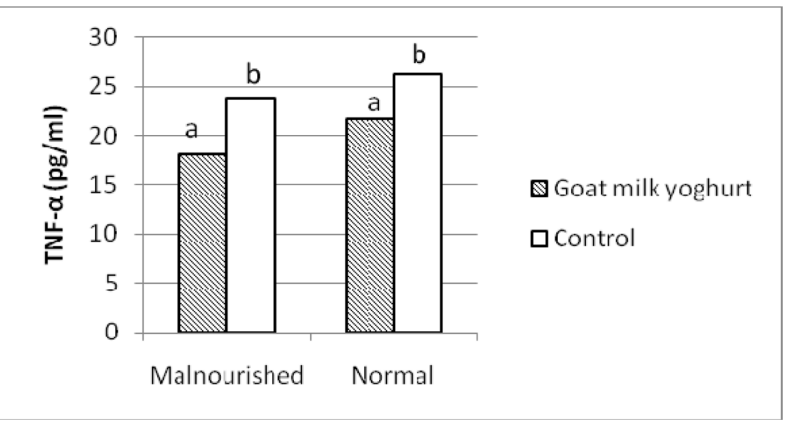

Fig. 3. Levels of TNF- $\alpha(\mathrm{pg} / \mathrm{mL})$ in supernatant splenocytes culture of malnourished and normal rat treated with goat milk yoghurt. (superscript with the different letter indicates significantly different)

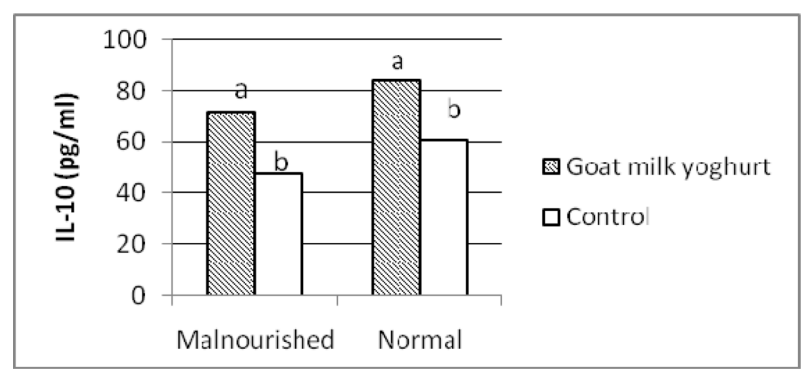

Fig. 4. Levels of IL-10 (pg/mL) in splenocytes culture supernatant culture of malnourished and and normal rat treated with goat milk yoghurt. (superscript with the different letter indicates significantly different)

$78.05 \pm 23.72 \mathrm{pg} / \mathrm{mL}$, whereas in the control rat was $53.80 \pm$ $18.79 \mathrm{pg} / \mathrm{mL}$.

\section{Discussion}

Malnutrition causes decreasing the weight depending on degree of malnutrition. According to Cortés-Barberena et al. (2008), the mild malnutrition or first degree when the weight deficit reached $10-25 \%$; moderate or second degree when the weight deficit reached $25-40 \%$; and severe or third degree when the weight deficit was greater than $40 \%$ of that of age-matched control rats. Increasing of rat body weight in this study after receiving goat milk yoghurt was nearly twice when compared to the control rat $7 \mathrm{~d}$ before. This is accordance with the previous study (Prada et al., 2007), in the rats treated with low protein diets for $60 \mathrm{~d}, 30 \mathrm{~d}$ of recovery feeding showed that body weight was twice when compared to that observed in the group one month before and no significant difference in proteinemia, albuminemia, circulating free fatty acid (FFA) levels and liver lipid content between the groups of low protein diets and normal protein. The low 
of body weight in malnourished rats in this study also similar to the other previous study using rats $5 \mathrm{wk}$ old with 55\% dietary restricted (Hubert et al., 2000) and protein restricted (Prada et al., 2007). Decreasing this body weight gain through by reducing the intake of calories or other nutrients per unit body mass (Hubert et al., 2000). The children on goat milk outgained the cow milk children in bodyweight over the 2-wk trial period and fat absorption tended to be better in the goat milk children (Razafindrakoto et al., 1993).

Splenocytes counts of moderate malnourished and normal Wistar rats in this study similar to the previous study (Cortés-Barberena et al., 2008), total splenic lymphocytes from normal Wistar rats was not significantly different with the moderate malnourished rats, but was significantly different between normal or moderate and severe malnourished rats. Maybe moderate malnutrition are not causing spleen damage that produces lymphocytes, but in the case of severe malnutrition occurs spleen damage. This possibility supported by the study effect of severe malnutrition in Wistar rats showed that malnutrition plays an important role in thymus and spleen atrophy by increasing the rate of spontaneous apoptosis, and indicate that severe malnutrition is associated with a significant increase of spontaneously apoptotic cells in the thymus (9.8-fold) and spleen (2.4-fold). These alterations may contribute to the immune suppression found in malnourished organisms (Ortiz et al., 2008).

The total number of lymphocyte from normal rats was higher than the diabetic rat $(260 \pm 23$ vs. $123 \pm 25) \times 10^{6} \%$ spleen, because that lymphocytes are more prone to injury in the diabetic state (Chi et al., 1982). In this study, the number of lymphocytes in normal or malnourished rat was lower (Table 3) than the lymphocytes in the previous study by Chi et al. (1982). This differences may be due to differences of age and species of rats, because lymphocytes number may also decrease with age, whereas splenic morphology is affected by species, age and genetic (Cesta, 2006), that also effects on lymphocytes number. According to Cheung and Nadakavukaren (1983), that age related to cellularity changes (cells/g of tissue) of the spleen of rats and the spleen increase in weight with age. In this study, source of lymphocytes using Wistar rats and previous study by Chi et al. (1982) using mixed of Wistar and Sprague Dawley rat lymphocytes.

Lactic acid bacteria (LAB) of goat milk yoghurt in this study was $9.1 \times 10^{8} \mathrm{CFU} / \mathrm{mL}$ and Bifidobacteria was $2.0 \times$ $10^{6} \mathrm{CFU} / \mathrm{mL}$. Supplementation this goat milk yoghurt for $7 \mathrm{~d}$ did not effect on lymphocyte number in spleen of nor- mal and malnourished rats. This results similar to the previous study by Galdeano and Perdigon (2006), L. casei with dose of $10^{8} \mathrm{CFU} / \mathrm{mouse} /$ day, that fed for $7 \mathrm{~d}$ did not influence the T-cell population of lamina propria in the mice small intestine.

There was no different between splenocyte proliferation response in moderate malnourished and normal rats fed goat milk yoghurt, because of the possibility of moderate malnutrition in rats no significant damage of the spleen as occurs in severe malnutrition. Giving yoghurt with a dose of $2 \mathrm{~mL} /$ day that containing LAB $9.1 \times 10^{8} \mathrm{CFU} / \mathrm{mL}$ and bifidobacteria $2.0 \times 10^{6} \mathrm{CFU} / \mathrm{mL}$ have no effect on proliferative response in normal and malnourished rats. First, this is because in normal (healthy) rats, yogurt supplementation is only used for the maintenance, and there is a homeostasis in the immune system and also there was no significant damage to the spleen in moderate malnutrition. Tolerance and homeostasis are maintained by specialized subsets of lymphocytes. Subsets of $\mathrm{CD}^{+} \mathrm{T}$ cells have drawn most of the attention so far, and there are several phenotypes, depending on the type of cytokines or surface molecules they express (Corthesy et al., 2007). Second, this possibility to occure spleen lymphocyte proliferation response is required a certain dose and duration of administration of probiotics and optimal mitogen concentration as well. According to Kirjavainen et al. (1999), L. rhamnosus GG (LGG) and Propionibacterium freudenreichii subsp. shermanii JS (PJS) have specific dose and duration-dependent immunomodulatory effects on the proliferative activity of $\mathrm{B}$ and $\mathrm{T}$ lymphocytes and may also reduce lymphocyte sensitivity to the cytotoxic effects of lectin mitogens. A significant decrease in basal lymphoproliferation (by 32 to $42 \%$ ) was observed with PJS treatment after the 3- and 7-d periods; however, this activity returned to control levels after $14 \mathrm{~d}$ of treatment, which also resulted in significantly enhanced T-cell proliferation at optimal and supraoptimal ConA concentrations (by 24 to $80 \%$ ). The $14 \mathrm{~d}$ LGG treatment also enhanced the latter activity (by $119 \%$ ). In this study using $5 \mu \mathrm{g} / \mathrm{mL}$ of PHA mitogen-specific $\mathrm{T}$ cell proliferation alone, so it is not stimulated B cells, and the PHA dose may also not optimal to induce lymphocyte proliferation response. Study by Palacios et al. (2007) using $60 \mu \mathrm{g} / \mathrm{mL}$ T-cell mitogen PHA, showed that in vitro lymphocyte proliferation stimulated by T-cell mitogens decreased with age in free-living vertebrate.

After supplemented with goat milk yoghurt, the average of IL-10 was higher (Fig. 4) than TNF level (Fig. 3). The results showed that goat milk yoghurt containing $L$. aci- 
dophilus, S. thermophilus and B. longum tend to induce anti-inflammatory cytokine in malnourished and normal rat. This results similar to the previous study using probiotic E. coli, that the probiotic strain was able to downregulate the increased levels of TNF- $\alpha$ both in the intestine from colitis rats, and in plasma and lungs in mice treated with LPS (Arribas et al., 2009). In addition, the ability of this probiotic bacterium $E$. coli to reduce TNF- $\alpha$ production in inflammatory conditions was also demonstrated in the trinitrobenzene sulfonic acid (TNBS) model of rat colitis or when it was evaluated in the dextran sodium sulfate (DSS)-induced colitis in mice (Grabig et al., 2006). TNF- $\alpha$ producing cells in the thymus increased significantly in the malnourished control group compared with the welnourished control group, and no significant differences were observed among the test groups, milk, probiotic fermented milk, and bacterial-free supernatant, where the values obtained were similar to the welnourished control group (Nunez et al., 2013). According to study by Galdeano et al. (2011), the administration of probiotic fermented milk as a dietary supplement during the re-nutrition process in a murine immunodeficiency model by malnutrition showed could be a good adjuvant diet to improve the gut and systemic immune response for the protection against Salmonella infection (Galdeano et al., 2011). This probiotics interact with immunocompetent cells using the mucosal interface and modulate locally the production of proinflammatory cytokines (Borruel et al., 2002). These proinflammatory cytokines are responsible for the presence of a chronic systemic inflammatory state, which shares numerous characteristics with the "acutephase response" found in critically ill patients (Mantovani et al., 2004). Practically, measurement of circulating levels of TNF- $\alpha$ would enable not only to identify malnourished patients in a more rapid and cost-effective way, but would also help to select those who might benefit from some type of nutritional intervention. Usually, malnourished patients had higher values of IL-1 and TNF- $\alpha$ (16.7 and $28.0 \mathrm{pg} / \mathrm{mL}$ ) (Correia et al., 2007).

Goat milk yoghurt containing L. acidophils, S. thermophilus and B. longum that supplemented in malnourished rats could increase the level of IL-10 in splenocytes culture supernatant and also in normal rats. This result similar to the previous study (Nunez et al., 2013) using mice that received probiotics fermented milk containing $L$. delbrueckii subsp. bulgaricus $\left(10^{8} \mathrm{CFU} / \mathrm{mL}\right)$ and S. thermophilus $\left(10^{8} \mathrm{CFU} / \mathrm{mL}\right)$ and the probiotic bacterium L. casei DN-114-001 $\left(10^{8} \mathrm{CFU} / \mathrm{mL}\right)$ during re-nutrition period showed significantly increased number of IL-10 produc- ing cells in the thymus. The increases of IL-10 can contribute to the decrease in cellular apoptosis observed after re-nutrition.

Probiotics in fermented milk was the most effective renutrition supplement to improve the histology of the thymus, decreasing cellular apoptosis in this organ (Nunez et al., 2013). Other previous study reported the effects of $E$. coli Nissle 1917 on the secretion of the cytokine IL-10 in Con A-activated splenocytes obtained from mice after LPS-induced septic shock (Arribas et al., 2009). That effects are dose dependent, which was shown after performing additional experiments with different doses of the probiotic E. coli coli strain Nissle $1917\left(10^{6}-10^{9}\right.$ CFU per mice) (Hockertz, 1997).

IL-10 is secreted by T lymphocytes, and monocytes play a central role in downregulating inflammatory cascades by suppressing the secretion of proinflammatory cytokines such as TNF- $\alpha$ (Kuhn et al., 1993; Van Furth et al., 1996). IL-10 also inhibits the production of chemokines by leukocytes and down regulates the expression of intercellular adhesion molecule 1 and chemoattractant proteins by endothelial cells, thus inhibiting leukocyte migration to the site of infection. In turn, TNF- $\alpha$ can induce the production of IL-10 upon stimulation with endotoxin (Van Furth et al., 1996).

In this study, goat milk yoghurt using Lacto-B powder directly, which consists of mixture three types of bacteria as much as $1 \times 10^{9} \mathrm{CFU} / \mathrm{mL}$. The total of LAB in the goat milk yoghurt was $9.1 \times 10^{8} \mathrm{CFU} / \mathrm{mL}$ and bifidobacteria was $2.0 \times 10^{6} \mathrm{CFU} / \mathrm{mL}$. This number of lactic acid bacteria still in the range according to Nunez et al. (2013). Anti-inflammatory effects such as stimulation of IL-10-producing cells, are strain-dependent traits, and their effectiveness also depends on the concentrations used and the method of administration. Oral administration of a probiotic mixture that consisted of B. longum Bar 33 and L. acidophilus Bar 13 prevented inflammation and mucosal ulcerations in a trinitrobenzene sulfonic acid- (TNBS-) induced colitis mouse model (Roselli et al., 2009). This protection was associated with an upregulation of IL-10 that caused an inhibition of the TNBS-induced increase of the $\mathrm{CD}^{+}$population, downregulation of IL-12, and a different pattern of Foxp $3^{+} \mathrm{CD} 4^{+} \mathrm{CD} 25^{+}$Treg cells in the intraepithelial and lamina propria lymphocytes (Mengheri, 2008). In other probiotic mixture containing L. acidophilus, L. casei, L. reuteri, B. bifidium, and S. thermophilus induced both Tcell and B-cell hyporesponsiveness and down-regulated Thelper (Th) 1, Th2, and Th17 cytokines without apoptosis induction in mice. It also induced gener- 
ation of $\mathrm{CD}^{+}$Foxp $3^{+}$Tregs from the CD4+CD25 population and increased the suppressor activity of naturally occurring. Conversion of $\mathrm{T}$ cells into Foxp $3^{+}$Tregs is directly mediated by regulatory dendritic cells (rDCs) that express high levels of IL-10, TGF- $\beta$, COX- 2 , and indoleamine 2,3-dioxygenase. The therapeutical effect of the probiotics is associated with enrichment of $\mathrm{CD}^{+} \mathrm{Foxp}^{+}$ Tregs in the inflamed regions (Kwon et al., 2010). The forkhead family protein Foxp3 (forkhead box P3) is a transcription factor highly expressed in $\mathrm{CD}^{+}$Tregs. It is a regulator of T-cell tolerance and is necessary for the development and function of Tregs (Ziegler, 2006).

The other previous study showed that a yoghurt produced with a pool of potentially probiotic LAB strains was effective in inhibiting the propagation of a dimethylhydrazine- (DMH-) induced colon cancer in mice by increasing the number of IL-10-secreting cells, increasing cellular apoptosis and decreasing procarcinogenic enzymes (deLeBlanc and Perdigon, 2010). By increasing IL10 levels and in consequently decreasing inflammatory cytokines such as TNF- $\alpha$ and IFN- $\gamma$, some LAB can prevent the appearance of local inflammatory diseases and could be used as an adjunct therapy with conventional treatments (de LeBlanc et al., 2011).

Components of food that is consumed, naturally have the potential to interact with a variety of lymphoid cells throughout the gastrointestinal tract. Protein administered orally, has been known to interact with specific secondary lymphoid organs such as tonsils and Peyer's patches. Complex interactions that occur on the side (lymphoid organs) is crucial for the development of the specific immune response. Several factors can influence the interactions, including the form of solids or liquids from food component and oral exposure methods (Sfeir et al., 2004). Immunomodulating requires intact or active peptides that are able to achieve immunocompetent cells. Most of the proteins are absorbed through the apical membrane of epithelial cells, which do not bind to the receptor will undergo lysosomal degradation (Perdue, 1999).

For the occurrence of the immune responses depends on the interaction with the active component with the immunocompetent cells, and immunogenicity of LAB in intestinal depends on degree of interaction with lymphoid tissue (Meydani and Ha, 2000). According to Sfeir et al. (2004), complex interactions between protein and immunocompetent cells is crucial for occurrence the specific immune response. Active component in yoghurt consists of bacterial and non-bacterial components that can role as immunomodulators (Meydani and Ha, 2000). Cell surface components in lactic acid bacteria, such as peptidoglycan, lipoproteins, and diacylated lipopeptide, act as ligands for immune cells that bind to Toll-like receptor (TLR) 2 and TLR1 or 6 heterodimers on the macrophage cell surface and then stimulate nitrite oxide (NO) production (Itoh et al., 2012).

The LAB are Gram-positive bacteria and their cell walls comprise a complex mixture of glycolipids, lipoproteins and phosphorylated polysaccharides embedded in a thick layer of peptidoglycan (PGN), a polymer of $\beta$-(1,4)-linked $\mathrm{N}$-acetylglucosamine and $\mathrm{N}$-acetylmuramic acid, crosslinked by short peptides. TLR2 has been shown to recognize lipoteichoic acid (LTA), lipoarabinomannan, lipoprotein (LP) and PGN, and is likely to be involved in the recognition of LAB. Lactic acid bacteria act as immunoregulators through interaction of lipoprotein with TLR2 and as immunostimulators through interaction of peptidoglycan with nucleotide-binding oligomerization domain2 (NOD2). As dendritic cell (DC) are potent stimulators of naive $\mathrm{T}$ cells and express several pattern recognition receptors (PRRs), they serve as an important link between the microbiota and polarization towards $\mathrm{T}$ helper type 1 (Th1), Th2- or regulatory T-cell-dominated environments. Cell surface-expressed and intracellularly expressed PRRs collectively recognize lipid, carbohydrate, protein and nucleic acid structures that are broadly expressed by different groups of microorganisms (Zeuthen et al., 2008).

Recognition of microbial components by TLRs initiates signal transduction pathways, which triggers expression of genes. These gene products control innate immune responses and further instruct development of antigen-specific acquired immunity. Individual TLRs play important roles in recognizing specific microbial components (Takeda and Akira, 2005).

The presence of LAB is thought to be essential for yoghurt to exert immunostimulatory effects but components of nonbacterial yogurt, such as whey protein, short peptides, and conjugated linoleic acid (CLA), are believed to contribute to yoghurt's beneficial effects as well. It is proposed that the LAB that survive through the gastrointestinal (GI) tract, whether intact or modified, can bind to the luminal surface of $\mathrm{M}$ cells. LAB-bound $\mathrm{M}$ cells reaching to the dome region of Peyer's patch (PP) cells stimulate local immune response, which can further activate the local immune system, resulting in stimulation of the local and the systemic immune response (Meydani and Ha, 2000). Whey protein had activity as an anti-allergy, anti-inflammatory, immunomodulatory and antioxidant. One of the proteins in the milk whey fraction which has the broadest 
range of biological activities related to the body's defense system, is lactoferrin, which among other acts as immunomodulator (Shimazaki et al., 1998; Zimecki and Kruzel, 2000). Study by Ward et al. (2002), showed that lactoferrin had been known inhibit allergen-induced skin inflammation in both mice and humans, most likely secondary to TNF- $\alpha$ production. The potency of probiotic bacteria to regulate immune responses is a complex interaction between the host immune system and different bacterial compounds, including chromosomal DNA and cell wall components as well as soluble metabolites (Corthesy et al., 2007).

The other non-bacterial component in goat milk yoghurt was prebiotics oligosaccharides. Acording to $\mathrm{Wu}$ et al. (2006), goat milk showed rich in sources of prebiotic oligosaccharides that resemble milk oligosaccharides (breast milk) (Bode, 2006), and in contrast to other prebiotics such as inulin or frukto short-chain oligosaccharides (Lara-Villoslada et al., 2006). The similarities found between human and goats' milk oligosaccharides in terms of the presence of neutral (galactosyl-lactose and lacto-N-hexaose) and sialylated (3-, 6-sialyl-lactose and disialyl-lactose) structures suggest that the latter may, to some extend, carry out or resemble physiological activities described for the former (Martinez-Ferez et al., 2006). Goat milk oligosaccharides also have anti-inflammatory effects in rats with experimental colitis and may be useful in the management of inflammatory bowel disease (Daddaoua et al., 2006).

In conclusions, supplementation of goat milk yoghurt in malnourished rats could decrease the pro-inflammatory cytokine, while it increases the anti-inflammatory cytokine, represented by TNF- $\alpha$ and IL-10 levels in the splenocyte culture supernatant, respectively. However, that goat milk yoghurt feeding does not give any effect on total splenocyte numbers and splenocyte proliferation.

\section{Acknowledgements}

The authors thank Prof. dr. Marsetyawan HNE Soesatyo, M.Sc., Ph.D for reading the manuscript. This research was supported partially by Anggaran Dana Masyarakat Universitas Gadjah Mada (Nomor LPPM-UGM/2175/BID.I/2012 TANGGAL 11 JULI 2012).

\section{References}

1. Al-Bana, N., Raghupathy, R., and Albert, M. J. (2008) Correlation of proinflammatory and anti inflammatory cytokine levels with histopathological changes in an adult mouse lung model of Campylobacter jejuni infection. Clin. Vaccine Immunol. 15, 1780-1787.

2. Alferez, M. J. M, Barrionuevo, M., Aliaga, I. L., Sanz-Sampelayos, M. R., Lisbona, F., Robles, J. C., and Campos, M. S. (2001) Digestive utilization of goat and cow milk fat in malabsorption syndrome. J. Dairy Res. 68, 451-461.

3. Arora, R., Bhojak, N., and Joshi, R. (2013) Comparative aspects of goat and cow milk. IJESI. 2, 7-10.

4. Arribas, B., Rodríguez-Cabezas, M. E., Camuesco, D., Comalada, M., Bailón, E., Utrilla, P., Nieto, A., Concha, A., Zarzuelo, A., and Gálvez, J. (2009) A probiotic strain of Escherichia coli, Nissle 1917, given orally exerts local and systemic antiinflammatory effects in lipopolysaccharide-induced sepsis in mice. Br. J. Pharmacol. 157, 1024-1033.

5. Baroja, M. L., Kirjavainen, P. V., Hekmat, S., and Reid, G. (2007) Anti-inflammatory effects of probiotic yogurt in inflammatory bowel disease patients. Clin. Exp. Immunol. 149, 470-479.

6. Bode, L. (2006) Recent advances on structure, metabolism, and function of human milk oligosaccharides. J. Nutr. 136, 2127-2130.

7. Borruel, N., Carol, M., Casellas, F., Antolín, M, de Lara, F., Espín, E., Naval, J., Guarner, F., and Malagelada, J. R. (2002) Increased mucosal tumour necrosis factor- $\alpha$ production in Crohn's disease can be downregulated ex vivo by probiotic bacteria. Gut 51, 659-664.

8. Cesta. (2006) Normal structure, function and histology of the spleen. Toxicol Pathol. 34, 455-465.

9. Cheung, H. T. and Nadakavukaren, M. J. (1983) Age-dependent changes in the cellularity and ultrastructure of the spleen of Fischer F344 rats. Mech Ageing Dev. 22, 23-33.

10. Chi, D. S., Berry, D. L., Dillon, K. A., and Arbogast, B. W. (1982) Inhibition of in vitro lymphocyte response by streptozotocin-induced diabetic rat serum. A Function of Very-LowDensity Lipoproteins. Diabetes 37, 1098-1104.

11. Correia, M., Cravo, M., Marques-Vidal, P., Grimble, R., DiasPereira, A., Faias, S., Nobre-Leitao, C. (2007) Serum concentrations of TNF-alpha as a surrogate marker for malnutrition and worse quality of life in patients with gastric cancer. $J$. Clin. Nutr. 26, 728-735.

12. Cortés-Barberena, E., González-Márquez, H., Gómez-Olivares, J. L., and Ortiz-Muñiz, R. (2008) Effects of moderate and severe malnutrition in rats on splenic $\mathrm{T}$ lymphocyte subsets and activation assessed by flow cytometry. Clin. Exp. Immunol. 152, 585-592.

13. Corthesy, B., Gaskins, H. R., and Mercenier, A. (2007) Crosstalk between probiotic bacteria and the host immune system. J. Nutr. 137, 781S-790S.

14. Daddaoua, A., Puerta, V., Requena, P., Martinez, F. A., Guadix, E., Sanches de M. F., Zarzuel, A., Suarez, D. M., Boza, J. J., and Martinez, A. O. (2006) Goat milk oligosaccharides are anti-inflammatory in rats with hapten-induced colitis. $J$. Nutr. 136, 672-676.

15. Dask, S. K. (2009). Selection Criteria for Probiotics. Presented at XXXVII Dairy Industry Conference, Kala Academy, Panjim, Goa. 
16. Dave, R. I. (1998). Factors affecting viability of yoghurt and probiotic bacteria in commercial starter cultures. A thesis submitted for the degree of Doctor of Philosophy. Centre for Bioprocessing and Food Technology, School of Life Sciences and Technology,Victoria University of Technology, Werribee Campus, Victoria, Australia.

17. de LeBlanc, A. M., del Carmen, S., Zurita-Turk, M., Rocha, C. S., van de Guchte, M., Azevedo, V., Miyoshi, A., and LeBlanc, J. G. (2011) Importance of IL-10 modulation by probiotic microorganisms in gastrointestinal inflammatory diseases. ISRN Gastroenterol. 11, 1-11.

18. de LeBlanc, A. M. and Perdigon, G. (2010) The application of probiotic fermented milks in cancer and intestinal inflammation. P. Nutr. Soc. 69, 421-428.

19. Dock, D. B., Agular-Nascimento, J. E., and Latorraca, M. Q. (2004) Probiotics enhance the recovery of gut atrophy in experimental malnutrition. Biocell 28, 143-150.

20. França, T. G. D., Ishikawa, L. L. W., Zorzella-Pezavento, S. F. G., Chiuso-Minicucci, F., da Cunha, M. L. R. S., and Sartori, A. (2009) Impact of malnutrition on immunity and infection. J. Venom. Anim. Toxins Incl. Trop. Dis. 15, 374-390.

21. Galdeano, C. M. and Perdigon, G. (2006) The probiotic bacterium Lactobacillus casei induces activation of the gut mucosal immune system through innate immunity. Clin Vaccine Immunol . 13, 219-226.

22. Galdeano, C. M., Núñez, I. N., de LeBlanc, A. M., Carmuega, E., Weill, R., and Perdigón, G. (2011) Impact of a probiotic fermented milk in the gut ecosystem and in the systemic immunity using a non-severe protein-energy-malnutrition model in mice. BMC Gastroenterol. 11, 6-14.

23. Giacinto, C. D., Marinaro, M., Sanchez, M., Strober, W., and Boirivant, M. (2005) Probiotics ameliorate recurrent Th1mediated murine colitis by inducing IL-10 and IL-10-dependent TGF- $\beta$-bearing regulatory cells. J. Immunol. 174, 32373246.

24. Grabig, A., Paclik, D., Guzy, C., Dankof, A., Baumgart, D. C., and Erckenbrecht, J. (2006). Escherichia coli strain Nissle 1917 ameliorates experimental colitis via toll-like receptor 2and toll-like receptor 4-dependent pathways. Infect Immun. 74, 4075-4082.

25. Hockertz, S. (1997) Augmentation of host defence against bacterial and fungal infections of mice pretreated with the non-pathogenic Escherichia coli strain Nissle 1917. Arzneimittelforschung 47, 793-796.

26. Hubert, M. F., Laroque, P., Gillet, J. P., and Keenan, K. P. (2000) The effect of diet, ad libitum feeding, and moderate and severe dietary on body weight, survival, clinical pathology parameters, and cause of death in control Sprague Dawley rats. Toxicol. Sci. 58, 195-207.

27. Itoh, T., Miyake, Y., Onda, A., Kubo, J., Ando, M., Tsukamasa, Y., and Takahata, M. (2012) Immunomodulatory effects of heat-killed Enterococcus faecalis TH10 on murine macrophage cells. MicrobiologyOpen 1, 373-380.

28. Jain, S., Yadav, H., Sinha, P. R., Naito, Y., and Marotta, F. (2008) Dahi containing probiotic Lactobacillus acidophilus and Lactobacillus casei has a protective effect against Sal- monella enteridis infection in mice. Int. J. Immunopathol. Pharmacol. 21, 1021-1029.

29. Keller, J. M., McClellan-Greena, P. D., Lee, A. M., Arendt, M. D., Maier, P. P., Segars, A. L., Whitaker, J. D., Keil, D. E., and Peden-Adams, M. M. (2005) Mitogen-induced lymphocyte proliferation in loggerhead sea turtles: Comparison of methods and effects of gender, plasma testosterone concentration, and body condition on immunity. Vet. Immunol. Immunopathol. 103, 269-281.

30. Kirjavainen, P. V., Elnezami, H. S., Salminen, S. J., Ahokas, J. T., and Wright, P. F. A. (1999) Effects of orally administered viable Lactobacillus rhamnosus GG and Propionibacterium freudenreichii subsp. Shermanii JS on mouse lymphocyte proliferation. Clin. Diagn. Lab. Immunol. 799-802.

31. Kompan, D. and Komprej, A. (2012) The effect of fatty acids in goat milk on health. In: Milk production - An up-to-date overview of animal nutrition, management and health. Chaiyabutr, N. (ed) InTech, Croatia, pp. 1-26.

32. Kuhn, R., Lohler, J., Rennick, D., Rajewsky, K., and Muller, W. (1993) Interleukin-10-deficient mice develop chronic enterocolitis. Cell 75, 263-274.

33. Kwon, H. K., Lee, C. G., So, J. S., Chae, C. S., Hwang, J. S., Sahoo, A., Nam, J. H., Rhee, J. H., Hwang, K. C., and Im, S. H. (2010) Generation of regulatory dendritic cells and CD4+ Foxp3+ T cells by probiotics administration suppresses immune disorders. PNAS. 107, 2159-2164.

34. Lara-Villoslada, F., Debras, E., Nieto, A., Concha, A., Gálvez, J., López-Huertas, E., Boza, J., Obled, C., and Xaus, J. (2006) Oligosaccharides isolated from goat milk reduce intestinal inflammation in a rat model of dextran sodium sulfate-induced colitis. Clin. Nutr. 25, 477-488.

35. Mantovani, G., Madeddu, C., Maccio, A., Gramignano, G., and Lusso, M. (2004) Cancer-related anorexia/cachexia syndrome and oxidative stress: An innovative approach beyond current treatment. Canc. Epidem. Biomark. Prev. 13, 16511659.

36. Martinez-Ferez, A., Rudloff, S., Guadix, A., Henkel, C. A., Pohlentz, G., Boza, J. J., Guadix, E. M., and Kunz, C. (2006) Goats' milk as a natural source of lactose-derived oligosaccharides: Isolation by membrane technology. Int. Dairy J. 16, 173-181.

37. Mengheri, E. (2008) Health, probiotics, and inflammation. $J$. Clin. Gastroenterol. 42, S177-178.

38. Meydani, S. N. and Ha, W. K. (2000) Immunologic effects of yogurt. Am. J. Clin. Nutr. 71, 861-872.

39. Nunez, I. N, Galdeano, C. M., Carmuega, E., Weill, R., de LeBlanc, A. M., and Perdigon, G. (2013) Effect of a probiotic fermented milk on the thymus in Balb/c mice under non-severe protein-energy malnutrition. Br. J. Nutr. 110, 500-508.

40. Ortiz, R., Cortés, L., Cortés, E., and Medina, H. (2008) Malnutrition alters the rates of apoptosis in splenocytes and thymocyte subpopulations of rats. Clin. Exp. Immunol. 155, 96106.

41. Palacios, M. G., Cunnick, J. E., Winkler, D. W., and Vleck, C. M. (2007) Immunosenescence in some but not all immune components in a free-living vertebrate, the tree swallow. Proc. 
R. Soc. 274, 951-957.

42. Park, Y. W. (1994) Hypo-allergenic and therapeutic significance of goat milk. Small Ruminant Res. 14, 151-159.

43. Pavlovic, H., Hardi, J., Slacanac, V., Halt, M., and Kocevski, D. (2006) Inhibitory effect of goat and cow milk fermented by Bifidobacterium longum on Serratia marcescens and Campylobacter jejuni. Czech J. Food Sci. 24, 164-171.

44. Perdue, M. H. (1999) Mucosal immunity and inflammation III. The mucosal antigen barrier: cross talk with mucosal cytokines. AM J. Physiol-Gastr L. 227, G1-G5.

45. Prada, F. J. A., Macedo, D. V., and de Melo, M. A. R. (2007) Oxidative stress during rehabilitation from protein malnutrition associated with aerobic exercise in rats. Braz. Arch. Biol. Technol. 50, 45-55.

46. Ramiro-Puig, E., Pérez-Cano, F. J., Ramírez-Santana, C., Castellote, C., Izquierdo-Pulido, M., Permanyer, J., Franch, A., and Castell, M. (2007) Spleen lymphocyte function modulated by a cocoa-enriched diet. Clin. Exp. Immunol. 149, 535542.

47. Razafindrakoto, O., Ravelomanana, N., Rasolofo, A., Rakotoarimanana, R. D., Gourgue, P., Coquin, P., Briend, A., and Desjeux, J. F. (1993) Le lait de chèvre peut-il remplacer le lait de vachechez l'enfant malnutri? Lait 73, 601-611.

48. Reeves, P. G., Neilsen, F. H., and Fahey, Jr. G. C. (1993) AIN93 purified diets for laboratory rodents: Final report of the American institute of nutrition Ad Hoc writing committee on the formulation of the AIN-76A Rodent Diet. J. Nutr. 123, 1939-1951.

49. Riskesdas. (2010) Riset Kesehatan Dasar. Kementerian Kesehatan Republik Indonesia.

50. Roselli, M., Finamore, A., and Nuccitelli, S. (2009) Prevention of TNBS-induced colitis by different Lactobacillus and Bifidobacterium strains is associated with an expansion of $\gamma \delta \mathrm{T}$ and regulatory $\mathrm{T}$ cells of intestinal intraepithelial lymphocytes. Inflamm. Bowel Dis. 15, 1526-1536.

51. Rosso, P., Keyou, G., Bassi, J. A., and Slusser, W. M. (1981) Effect of malnutrition during pregnancy on the development of the mammary glands of rats. J. Nutr. 111, 1937-1941.

52. Sartor, R. B. (2011). Efficacy of Probiotics for the management of inflammatory bowel disease. J Gastroen Hepatol. 7, 606-608.

53. Savino, W. (2002) The thymus gland is a target in malnutrition. Eur. J. Clin. Nutr. 56, S46-S49.

54. Semaeva, E., Tenstad, O., Skavland, J., Enger, M., Iversen, P. O., Gjertsen, B. T., and Wiig, H. (2010) Access to the spleen microenvironment through lymph shows local cytokine pro- duction, increased cell flux, and altered signaling of immune cells during lipopolysaccharide-induced acute inflammation. J. Immunol. 184, 4547-4556.

55. Sfeir, R. M., Dubarry, M., Boyaka, P. N., Rautureau, M., and Tome, D. (2004) The mode of oral bovine lactoferrin administration influences mucosal and systemic immune reponses in mice. $J$. Nutr. 134, 403-409.

56. Shimazaki, K., Tazume, T., Uji, K., Tanaka, M., Kumura, H., Mikawa, K., and Shimo-Oka, T. (1998) Properties of a heparin-binding peptide derived from bovine lactoferrin. J. Dairy Sci. 81, 2841-2849.

57. Silankove, N., Leitner, G., Merin, U., and Prosser, C. G. (2010) Recent advances in exploiting goat's milk: Quality, safety and production aspects. Small Ruminant Res. 89, 110-124.

58. SPSS. (2003) Statistical package for social sciences for windows (version 12.0). Chicago, IL: SPSS Inc.

59. Sunarlim, R. (2009) Potensi Lactobacillus, sp asal dari dadih sebagai starter pada pembuatan susu fermentasi khas Indonesia. Buletin Teknologi Pascapanen Pertanian. 5, 69-76.

60. Takeda, K. and Akira, S. (2005) Toll-like receptors in innate immunity. Int. Immunol. 17, 1-14.

61. Van Furt, A. M., Roord, J. J., and van Furth R. (1996) Roles of Proinflammatory and Anti-Inflammatory cytokines in pathophysiology of bacterial meningitis and effect of adjunctive therapy. Infect. Immun. 64, 4883-4890.

62. Ward, P. P., Uribe-Luna, S., and Conneely, O. M. (2002) Lactoferrin and host defense. Biochem. Cell Biol. 80, 95-102.

63. WHO. (2006) Food and nutrition policy for schools: A tool for the development of school nutrition programmes in the European Region. Programme for Nutrition and Food Security. WHO Regional Office for Europe. Copenhagen.

64. Wu, F. Y., Tsao, P. H., Wang, D. C., Lin, S., Wu, J., and Cheng, Y. K. (2006) Factors affecting growth factor activity in goat milk. J. Dairy Sci. 89, 1951-1955.

65. Zeuthen, L. H., Fink, L. N., and Frøkiær, H. (2008) Toll-like receptor 2 and nucleotide-binding oligomerization domain-2 play divergent roles in the recognition of gut-derived lactobacilli and bifidobacteria in dendritic cells. J. Immunol. 124, 489-502.

66. Ziegler, S. F. (2006) FOXP3: Of Mice and Men. Annu. Rev. Immunol. 24, 209-226.

67. Zimecki, M. and Kruzel, M. L. (2000) Systemic or local coadministration of lactoferrin with sensitizing dose of antigen enhanches delayed type hypersensitivity in mice. Immunol Lett. 74, 183-188.

(Received 2013.10.1/Revised 2013.12.9/Accepted 2014.1.23) 